\title{
Purification and characterization of a phytoalexin elicitor from spores of the saprobe Mucor ramosissimus ${ }^{1}$
}

\author{
KELLY SIMÕES ${ }^{2}$, SONIA M.C. DIETRICH ${ }^{3}$, MICHAEL G. HAHN $^{4}$ and MARCIA R. BRAGA ${ }^{3,5}$
}

(received: July 11, 2004; accepted: October 20, 2005)

\begin{abstract}
Purification and characterization of a phytoalexin elicitor from spores of the saprobe Mucor ramosissimus). Plants accumulate antimicrobial compounds (phytoalexins) in response to a wide variety of microorganisms. Mucor ramosissimus Samutsevitsch is a saprobe capable of inducing phytoalexin production in soybean cotyledons and in the leaves of tropical Rubiaceae on whose surface it has been found. In the present study, the elicitor from M. ramosissimus was partially purified and the activity compared to that of a glucan elicitor isolated from Phytophthora sojae. Optimal isolation of the elicitor (based on fungal growth, yield of spores and elicitor activity) was achieved by autoclaving spores obtained from nine day-old cultures of the fungus. The elicitor was precipitated with ethanol and purified by chromatography on an anion exchange column, which retained the elicitor, and a Concanavalin A-affinity matrix, to which the elicitor did not bind. The purification resulted in a considerable increase (six-fold) in the specific activity of the elicitor. Neutral sugar composition, analyzed by HPLC, revealed the predominance of mannose, followed by glucose and galactose, whereas colorimetric quantification showed the presence of uronic acids. GC-MS analysis of the elicitor revealed the predominance of glucuronic acid and mannose. These results suggest that fragments of mucoran-type polysaccharides are the phytoalexin elicitors present in the spores of the saprobe $M$. ramosissimus. Our results also indicate for the first time that soybean cotyledon tissues can recognize fragments of glucuronic-acid heteropolymers as phytoalexin elicitors.
\end{abstract}

Key words - elicitor, Mucor ramosissimus, mucoran, phytoalexin, saprobe fungus, soybean

RESUMO - (Purificação e caracterização de um eliciador de fitoalexinas de esporos do fungo sapróbio Mucor ramosissimus). Plantas acumulam compostos antimicrobianos (fitoalexinas) em resposta a uma grande variedade de microorganismos. Mucor ramosissimus Samutsevitsch é um fungo sapróbio capaz de induzir a produção de fitoalexinas em soja e em Rubiaceae nativas, sobre a superfície das quais ele é encontrado. Neste estudo, o eliciador de esporos de M. ramosissimus foi parcialmente purificado e sua atividade comparada ao glucano isolado de Phytophthora sojae. O ótimo de isolamento do eliciador (baseado no crescimento do fungo, no rendimento dos esporos e na atividade eliciadora) foi obtido a partir de esporos autoclavados de culturas do fungo com nove dias de idade. O eliciador foi precipitado com etanol e purificado por cromatografia de troca iônica, a qual reteve o eliciador, e por uma matriz de afinidade em Concanavalina-A, à qual o eliciador não se ligou. A purificação resultou em considerável aumento (seis vezes) de atividade específica do eliciador. Análises de açúcares neutros por HPLC revelaram a predominância de manose, seguida de glucose e galactose, enquanto que a quantificação por colorimetria mostrou a presença de ácidos urônicos. Análises do eliciador por GC-MS indicaram a predominância de ácido glucurônico e manose. Esses resultados sugerem que fragmentos de um polissacarídeo do tipo mucorano são os eliciadores de fitoalexinas presentes nos esporos de M. ramosissimus. Os resultados também indicam, pela primeira vez, que os tecidos de cotilédones de soja reconhecem fragmentos de heteropolímeros de ácidos urônicos como eliciadores de fitoalexinas.

Palavras-chave - eliciador, fitoalexinas, fungo sapróbio, Mucor ramosissimus, mucorano, soja

\section{Introduction}

The synthesis of antimicrobial compounds named phytoalexins is one of the best-studied defensive

1. Part of the MSc. thesis of K. Simões, Instituto de Biologia, Universidade Estadual de Campinas, Campinas.

2. Universidade Estadual de Campinas, Departamento de Biologia Celular, Caixa Postal 6109, 13083-863 Campinas, SP, Brasil.

3. Instituto de Botânica, Seção de Fisiologia e Bioquímica de Plantas, Caixa Postal 4005, 01061-970 São Paulo, SP, Brasil.

4. University of Georgia, Complex Carbohydrate Research Center, 315 Riverbend Road, 30602-4712 Athens, GA, USA.

5. Corresponding author: bragamr@ig.com.br responses of plants to pathogens (Dixon \& Lamb 1990). Phytoalexin production is observed not only after microbial infection, but also after diverse biotic and abiotic stresses. In addition, cell-free extracts of microbial and plant origin, as well as inorganic and organic substances can trigger the synthesis of these compounds in plant species. The inducing molecules are referred to as elicitors, the term being commonly used to describe molecules capable of stimulating any plant defensive mechanism (Côté et al. 1995, Nürnberger 1999).

Different eliciting substances isolated from fungi have been shown to induce phytoalexin accumulation in 
several plant species (Hahn 1996, Shibuya \& Minami 2001 , and references therein). Among them, the $\beta-1,3$ $\beta-1,6$ branched glucan isolated from mycelial cell walls or cultures filtrates of Phytophthora sojae - a natural soybean pathogen - has been considered the most potent elicitor described (Ayers et al. 1976a, Cheong et al. 1991, Hahn 1996). Besides glucans, fragments of chitin and chitosan have also been characterized as elicitors of fungal origin (Shibuya \& Minami 2001, Agrawal et al. 2002). The extent of biochemical information available on elicitor signals and on cellular response resulting in the biosynthesis and accumulation of phytoalexins in soybean make this system particularly attractive for studies of signaling mechanisms in plants (Côté et al. 1995).

The phytoalexins from soybean (glyceollins) are pterocarpans derived from the phenylpropanoid pathway and occur as a series of isomers (I-IV) (Paxton 1995). The isoflavone daidzein is the immediate precursor of the glyceollins (Paxton 1995) and genistein (trihydroxylated isoflavone) is another anti-microbial isoflavone that is accumulated in soybean tissues in response to fungal elicitors (Rivera-Vargas et al. 1993, Graham \& Graham 2000). Both daidzein and genistein are present as large pools of pre-formed conjugates in soybean seedling tissues, being released by hydrolysis in response to incompatible interaction with pathogens or treatment with fungal or plant elicitors (Graham et al. 1990, Graham 1995).

Some saprobe fungi such as Heterobasidion annosum can induce defensive responses in plants even though they are not capable of invading their tissues (Asiegbu et al. 1994). Other saprobe fungi have been described as inducers of phytoalexin accumulation in wild dicotyledonous plants as well as in soybean (Braga et al. 1986, Braga \& Dietrich 1991, Cordeiro Neto \& Dietrich 1992), the inducing activity being comparable to that of pathogenic species (Costa \& Dietrich 1996, Garcéz et al. 2000). Included among these fungi is Mucor ramosissimus Samutsevitsch, a filamentous Zygomycete commonly found in soil, litter, or on plant surfaces (Ellis 1997).

Spores of M. ramosissimus are found on the leaf surface of Rubiaceae species in tropical environments during the autumn and winter periods (Cordeiro Neto $\&$ Dietrich 1992). Live and autoclaved spore suspensions of $M$. ramosissimus were shown to be potent inducers of phytoalexin production in detached leaves of these Rubiaceae and in soybean cotyledons (Cordeiro Neto \& Dietrich 1992, Goméz et al. 1994, Pelicice et al. 2000). Garcéz et al. (2000) compared the phytoalexin-eliciting activity of this fungus with a saprobe Rhizopus species and observed that only spores of $M$. ramosissimus were capable of inducing phytoalexin response in soybean cultivars susceptible to frog-eye spot and stem canker disease. In spite of its potent phytoalexin-inducing activity, the elicitor isolated from spores of $M$. ramosissimus has not yet been characterized.

In the present work, we report the purification and partial characterization of the elicitor from ungerminated spores of $M$. ramosissimus and the comparison of its phytoalexin-eliciting capacity with that of the widely known $\beta$-glucan from $P$. sojae.

\section{Material and methods}

Microorganism and culture conditions - Mucor ramosissimus Samutsevitsch (URM 3106 - Universidade Federal de Pernambuco, Recife, PE, Brazil) was cultivated in SMA (Synthetic-Mucor-Agar) containing (g.L $\left.\mathrm{L}^{-1}\right)$ : glucose (40.0), asparagine (2.0), $\mathrm{K}_{2} \mathrm{PO}_{4}(0.5), \mathrm{MgSO}_{4}(0.25)$, thiamine (0.05 mg.L $\mathrm{L}^{-1}$ ) and agar (10.0) (Schipper 1973). Cultures were grown in Petri dishes containing $20 \mathrm{~mL}$ of SMA medium in darkness at $28^{\circ} \mathrm{C}$ for different periods.

Growth curve and sporulation - Mycelial samples of six mm diameter were taken from ten-day-old actively growing, sporulating cultures of M. ramosissimus and placed in the center of Petri dishes (three plates for each day), on SMA medium. The plates were incubated as described above and the diameter of each colony was measured daily. Spores were harvested by adding $20 \mathrm{~mL}$ of sterile distilled water to the plate and gently scraping the spores from the culture surface into the solution using a fine brush. Samples of the spore suspension were used for spore counting in a Newbauer chamber.

Elicitor extraction - Spore suspensions of M. ramosissimus from six to 11-day old cultures obtained as described above were filtered in cheesecloth. After filtration, the suspensions were centrifuged $10 \mathrm{~min}$ at $318 \mathrm{~g}$ and the supernatant was discarded. Spores were resuspended in distilled water and autoclaved for $30 \mathrm{~min}$ at $121^{\circ} \mathrm{C}$ at $1.5 \mathrm{~atm}$. The supernatant was collected by centrifugation at $6,000 \mathrm{~g}$ for $30 \mathrm{~min}$ at $5{ }^{\circ} \mathrm{C}$ and stored at $-20{ }^{\circ} \mathrm{C}$. The pellet was discarded. All these procedures were performed under asseptic conditions. The $\beta$-glucan elicitor was obtained from mycelium cell walls of Phytophthora sojae as described by Hahn et al. (1992).

Assay of eliciting activity - The phytoalexin eliciting activity was evaluated by the soybean cotyledon assay (Ayers et al. 1976b) using Glycine max L. cultivar IAC-18 (Instituto Agronômico de Campinas, SP, Brazil). Soybean seeds were germinated under controlled conditions as described by Pelicice et al. (2000). The cotyledons were detached from 9-day-old plantlets and soaked in $10 \%$ commercial sodium hypochlorite for $15 \mathrm{~min}$, and subsequently washed 
thoroughly with distilled water. A sterilized cork borer of $0.8 \mathrm{~cm}$ diameter was used to delimitate the area of the $1 \mathrm{~mm}$-deep well that was created with a sterile scalpel. The wounded surface was treated with $50 \mu$ l of one of the following solutions: distilled water (control), elicitor extracted from spores of $M$. ramosissimus $\left(50 \mu \mathrm{g}\right.$ glucose equivalents. $\left.\mathrm{mL}^{-1}\right)$, or the $\beta$-glucan elicitor from mycelial walls of Phythophthora sojae (2 $\left.\mu \mathrm{g} . \mathrm{mL}^{-1}\right)$. For all experiments, $2.5 \mu \mathrm{g}$ glucose equivalents.cotyledon ${ }^{-1}$ were used, except for the doseresponse curve in which the amount of the $M$. ramosissimus elicitor ranged from 0 to $10 \mu \mathrm{g}$.cotyledon ${ }^{-1}$. Groups of five cotyledons in triplicate were used per each treatment. The cotyledons were kept in a Petri dish containing waterabsorbed filter paper in the dark at $26^{\circ} \mathrm{C}$ for $20 \mathrm{~h}$. The cotyledons were washed with deionized water $(1 \mathrm{~mL}$ per cotyledon) to collect the diffusates, which were used to estimate phytoalexin production by spectrophotometry at $286 \mathrm{~nm}$ and for quantification by High Performance Liquid Chromatography (HPLC) as described below.

Quantification of phytoalexins - Diffusates from the soybean cotyledon assay (15 cotyledons) underwent liquid-liquid extraction with ethyl acetate, as described by Keen (1978). Organic fractions were evaporated to dryness, and the residues then solubilized in methanol and analyzed by HPLC in a Shimadzu chromatograph fitted with a UV-VIS detector. The samples were run on a $4.6 \mathrm{~mm} \times 250 \mathrm{~mm}$ Shimadzu CLS ODS C18 column with a linear gradient from $20 \%$ to $60 \%$ acetonitrile in $0.1 \%$ trifluoroacetic acid $\left(0.8 \mathrm{~mL} \cdot \mathrm{min}^{-1}\right)$ according to Pelicice et al. (2000). Peak area versus compound concentration was plotted for various concentrations of available standards. Daidzein and genistein were identified by calibration with authentic standards (Sigma; St. Louis, MO), whereas diffusates from $\beta$-glucan elicitor-treated cotyledons of the Williams 82 soybean cultivar (from Illinois Foundation Seeds, Inc., USA) were used as the glyceollin standard. The compounds were monitored at $286 \mathrm{~nm}$.

Elicitor fractionation - The supernatant obtained from autoclaved spore suspensions of 9-day old $M$. ramosissimus cultures $\left(15 \times 10^{9}\right.$ spores. $\left.\mathrm{mL}^{-1}\right)$ was concentrated to $1 / 10$ of its original volume and precipitated with 5 volumes of ethanol at $5^{\circ} \mathrm{C}$ for $72 \mathrm{~h}$. The precipitate recovered by centrifugation $\left(10,000 \mathrm{~g}, 5^{\circ} \mathrm{C}, 30 \mathrm{~min}\right)$ was washed twice in ethanol, and resuspended in deionized water to $1 \mathrm{mg}$ total sugar per $\mathrm{mL}$, determined by the phenol-sulfuric procedure (Dubois et al. 1956). The solution was subjected to Fast Performance Liquid Chromatography (FPLC) anion exchange chromatography in a $1 \mathrm{~mL}$ Q-trap column (Pharmacia) and eluted using an initial wash with $10 \mathrm{mM}$ ammonium bicarbonate $(10 \mathrm{~min})$, followed by a linear gradient of 10-500 $\mathrm{mM}$ ammonium bicarbonate for $50 \mathrm{~min}$, and a final wash with $1 \mathrm{M}$ ammonium bicarbonate for another $10 \mathrm{~min}$ at a flow rate of $1 \mathrm{~mL} \cdot \mathrm{min}^{-1}$. Fractions of $1 \mathrm{~mL}$ were collected and analyzed for carbohydrate and protein (see below) and eliciting activity. The active fractions were lyophilized and resuspended ( $1 \mathrm{~mL}$ ) in $100 \mathrm{mM}$ Tris buffer $\mathrm{pH}$ 7.4 containing $100 \mathrm{mM}$ sodium acetate, $150 \mathrm{mM} \mathrm{NaCl}, 1 \mathrm{mM}$
$\mathrm{CaCl}_{2}, 1 \mathrm{mM} \mathrm{MgCl}$. This solution was applied to a $1 \mathrm{~mL}$ column of Con A Sepharose (Pharmacia) previously washed with the same buffer in an FPLC system. The column was eluted with $10 \mathrm{~mL}$ of the buffer while collecting $2 \mathrm{~mL}$ fractions, and subsequently eluted with $5 \mathrm{~mL}$ of $100 \mathrm{mM} \alpha$-methyl-Dmannopyranoside (Sigma) in the same buffer. The elicitor material without affinity for the Con A Sepharose was quantified for carbohydrate and protein contents (as described below), pooled, and dialyzed (MW cut off of 1,000 Daltons) exhaustively against deonized water. The Con A binding material was also dialyzed under the same conditions. The elicitor material without affinity for the Con A Sepharose was subsequently applied into a $1.0 \times 20.0 \mathrm{~cm}$ column of Bio Gel P-2 (Bio Rad) equilibrated with distilled water. Maltoheptaose, maltotetraose, and sucrose were used as standards for column calibration. The amounts of total carbohydrates and proteins in each fraction were determined as described below.

Determination of carbohydrate and protein contents - The amounts of total carbohydrates were determined by the phenol-sulfuric acid method (Dubois et al. 1956) using glucose as standard. Uronic acid content was determined using a modification of the $m$-hydroxibiphenyl procedure (Filisetti-Cozzi \& Carpita 1991) using galacturonic acid as standard. Proteins were monitored by absorbance at $280 \mathrm{~nm}$ and quantified by the procedure described by Bradford (1976) with bovine serum albumin as standard.

Analysis of sugar composition and glycosyl linkages - The neutral sugar composition of elicitor-active fractions were determined by hydrolysis in $2 \mathrm{M}$ trifluoroacetic acid at $121^{\circ} \mathrm{C}$ for $2 \mathrm{~h}$. The resulting monosaccharides were separated and quantitated by High Performance Anion Exchange Chromatography with a Pulsed Amperometric Detector (HPAEC/PAD) in a Dionex DX-500 system on a Carbo-Pac PA-1 column using isocratic $12 \mathrm{mM} \mathrm{NaOH}$ as eluent. The flow rate through the column was $1 \mathrm{~mL} \cdot \mathrm{min}^{-1}$. The elution time of each sugar was compared to those of monosaccharide standards.

The elicitor-active material without affinity for Con A Sepharose was hydrolyzed as described above, trimethylsilylated (TMS) with Tri-Sil, and analyzed by gas chromatography coupled with mass spectrometry (GC-MS) (York et al. 1985). The following temperature conditions were used: $160^{\circ} \mathrm{C}$ for $3 \mathrm{~min}$ and increased to $260^{\circ} \mathrm{C}$ at $10^{\circ} \mathrm{C} \cdot \mathrm{min}^{-1}$. Myo-inositol was used as an internal standard.

Periodate and protease treatments - Periodate oxidation of the elicitor was carried out according to the procedure modified from De Wit \& Roseboom (1980). Briefly, $50 \mu \mathrm{g}$ glucose equivalents were incubated with $70 \mathrm{mM}$ sodium periodate (Merck) for $24 \mathrm{~h}$ at $30^{\circ} \mathrm{C}$ in the dark. Excess of periodate was eliminated by addition of $100 \mu \mathrm{l}$ of ethylene glycol. Protease treatment was performed by incubation of the elicitor with protease IV (Sigma) (4.1 units. $\mathrm{mL}^{-1}$ ) in $10 \mathrm{mM}$ sodium phosphate buffer, pH 7.0 for $24 \mathrm{~h}$ at $30^{\circ} \mathrm{C}$. The reaction was stopped by boiling the extracts for $2 \mathrm{~min}$. Controls were 
performed with elicitor without treatments and with samples containing distilled water instead of the elicitor incubated in the same conditions. The eliciting activity was evaluated in soybean cotyledons as described above.

\section{Results and Discussion}

M. ramosissimus grew rapidly in SMA medium, the exponential growth phase being observed from 0 to 4 days (figure 1A). After 6 days, the mycelium completely covered the medium surface. Sporulation started on day 4 and maximal spore production occurred from nine to 13 days in culture (figure $1 \mathrm{~B}$ ). The yield of spores on SMA medium was ca.10 times higher than that previously described for the fungus grown on PDA (Potato-Dextrose-Agar medium) (Cordeiro Neto 1992).

Although spore yields were quite similar from four to nine day-old cultures, the carbohydrate content in the elicitor extracts obtained from autoclaved spores increased after six days of culture (figure 1B), indicating that the components of the spores differed from early to late sporulation stages.

The phytoalexin eliciting activity of the $M$. ramosissimus spore extracts, as measured by the soybean cotyledon bioassay, reached a maximum for extracts of spores from eight-nine day-old cultures (figure 1C). Quantification by HPLC also indicated that accumulation of glyceollins is maximal on day 9 and that the precursor daidzein is also induced by the elicitor, while genistein accumulation remains relatively unaffected by elicitor treatment regardless of the age of the fungal culture (figure 1D).

Precipitation of nine-day-old culture extracts with ethanol appeared to enrich for glyceollin-inducing components of the elicitor preparation (figure 2). The dose-response curve performed with the crude

A

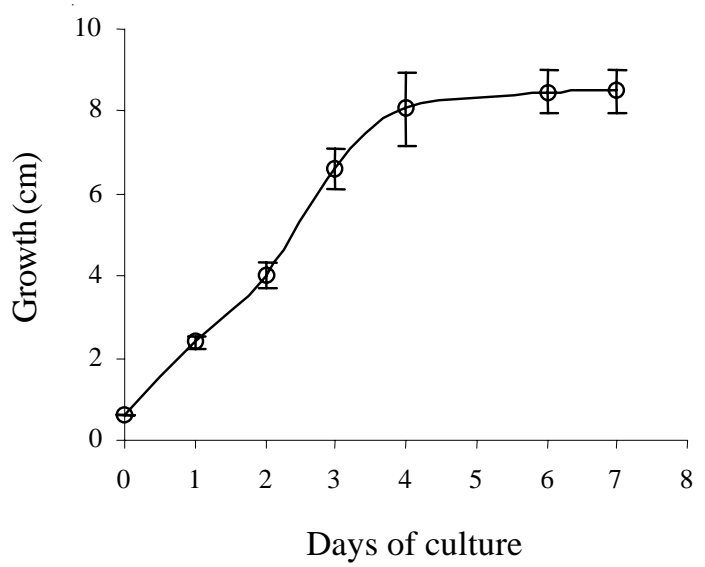

C

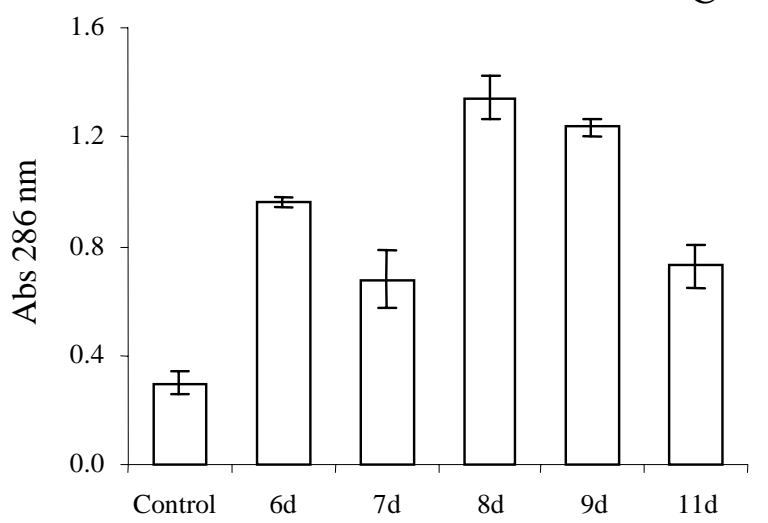

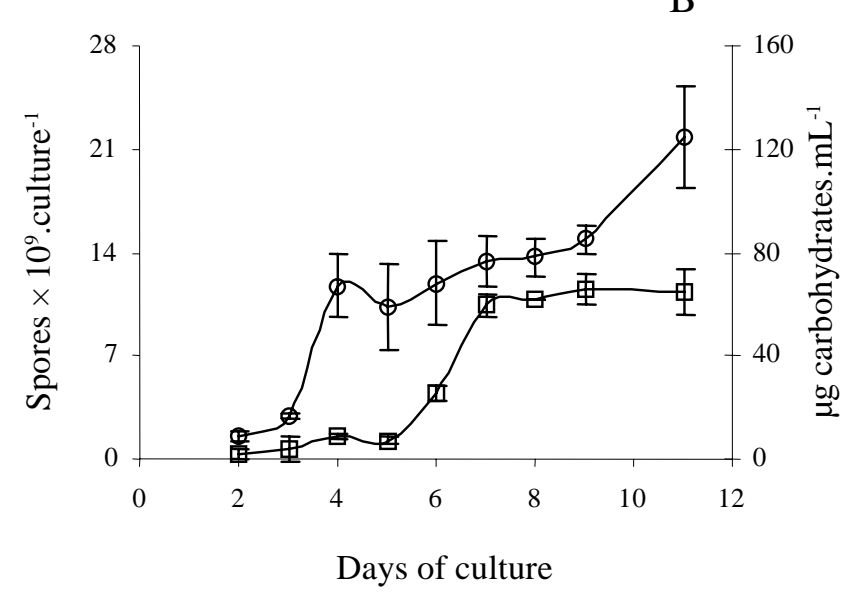

D

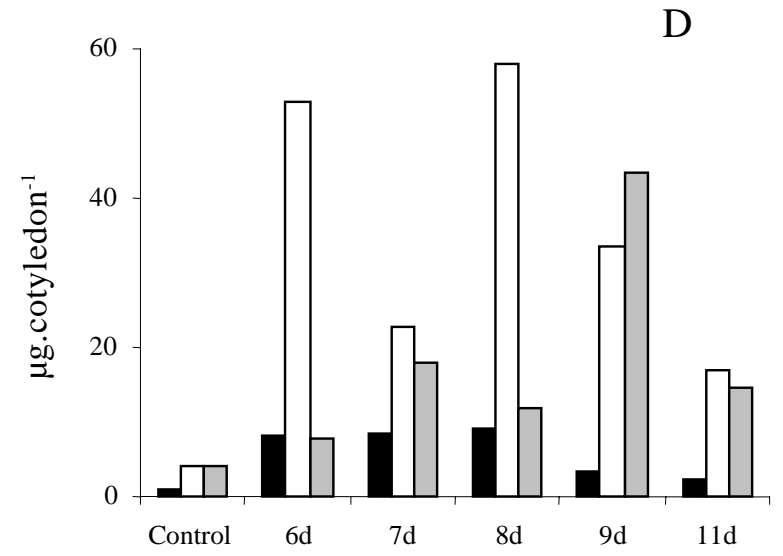

Figure 1. Growth, sporulation, and eliciting activity of Mucor ramosissimus grown in SMA medium. (A) Diameter of the fungal colony. (B) Sporulation (O) and carbohydrate content in the autoclaved spore suspension ( $\square$ ). (C) and (D) Eliciting activity of suspensions of autoclaved spores from cultures of different ages measured by absorbance at $286 \mathrm{~nm}$ and by HPLC, respectively. (ם) Genistein, $(\square)$ daidzein and ( $\square$ ) glyceollins in diffusates of soybean cotyledons assayed with distilled water (control) or autoclaved spore suspensions. $2.5 \mu \mathrm{g}$ of glucose equivalents of the elicitor were applied per cotyledon. Data represent the mean \pm standard deviation of triplicates. 
precipitated elicitor of $M$. ramosissimus revealed that glyceollin and daidzein accumulations increase as increasing amounts of elicitor are applied per cotyledon (figure 3).

The fractionation of the crude precipitated elicitor using anion exchange chromatography is shown in figure 4A. Most of the carbohydrate-containing material eluted from the Q-trap column in the ammonium bicarbonate gradient. Fractions were pooled based on their carbohydrate contents and assayed on for elicitor activity on soybean cotyledons. Elicitor activity was detected in all bound fractions, although the highest glyceollin accumulations were induced by the fractions designated as G2, G3, G4 and that eluted with $1 \mathrm{M}$ bicarbonate buffer (figure 4B). Neutral sugar composition analysis of the elicitor-active fractions showed the presence of mannose, glucose and galactose and small amounts of arabinose (table 1). Mannose was the major component in all fractions although its proportion decreased with the increased charge of the molecules and their elicitor activity (table 1, figure 4B).

Although the active fractions from the anion exchange column contained Bradford-positive material (ca. $2 \mu \mathrm{g} . \mathrm{mL}^{-1}$ ), treatment with protease did not reduce elicitor activity, suggesting that this activity is not attributable to peptide components of the fractions (data not shown). In contrast, the elicitor activity was completely abolished by periodate oxidation indicating that the activity resides in the carbohydrate moiety (data not shown). These results are consistent with the thermal stability of the $M$. ramosissimus elicitor, which was

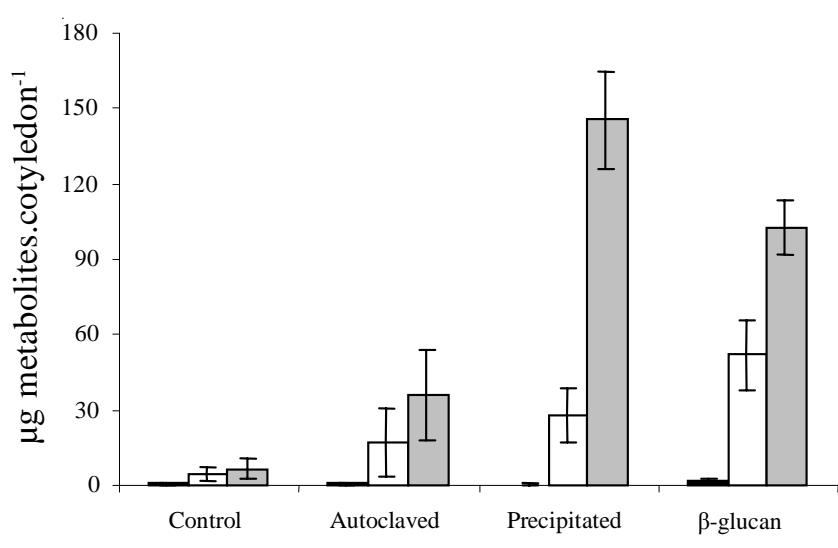

Figure 2. Eliciting activity of autoclaved spores of M. ramosissimus and ethanol-precipitated extract on soybean cotyledons. Values represent the amounts of $(\boldsymbol{\square})$ genistein, $(\square)$ daidzein and $(\square)$ glyceollins in the diffusates measured by HPLC. $2.5 \mu \mathrm{g}$ of glucose equivalents of the Mucor elicitor and $0.1 \mu \mathrm{g}$ of the $\beta$-glucan of $P$. sojae were applied per cotyledon.

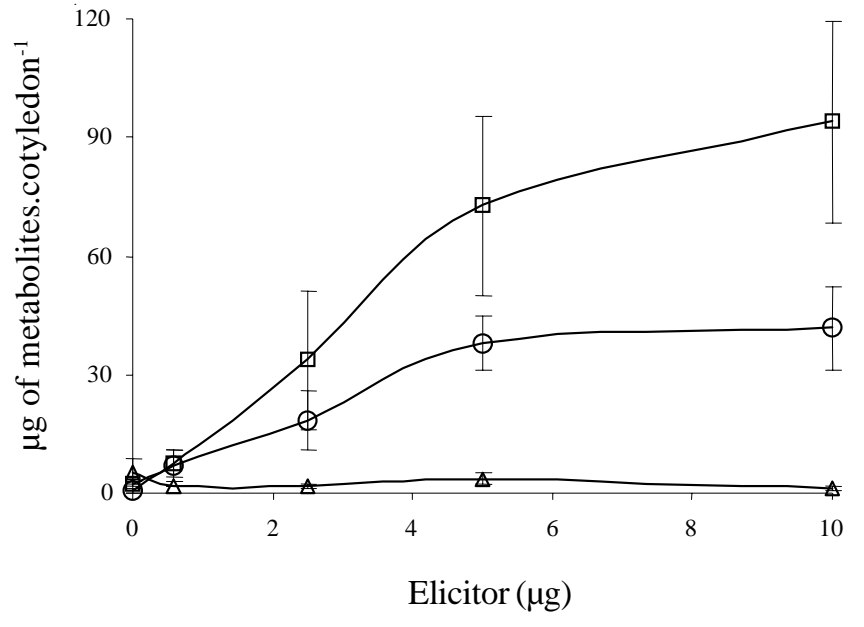

Figure 3. Dose-response eliciting curve of the ethanolprecipitated extract from spores of 9-day-old cultures of M. ramosissimus. Values represent the amounts of $(\triangle)$ genistein, (O) daidzein and $(\square)$ glyceollins in soybean diffusates measured by HPLC. Data represent the mean \pm standard deviation of triplicates.

obtained by autoclaving the spores for $30 \mathrm{~min}$. Similar results were obtained for phytoalexin elicitors obtained from Colletotrichum spp., Phytophthora megasperma var. sojae, Saccharomyces cerevisae, and Hemileia vastatrix (Ayers et al. 1976a, Hahn \& Albersheim 1978, Yoshikawa et al. 1981, Guzzo \& Moraes 1997). The binding of the $M$. ramosissimus elicitor to the ionexchange column can be attributed to the presence of uronic acids in the extracts (table 2).

Further purification of the Mucor elicitor was achieved by Concanavalin-A (Con-A) affinity chromatography. Non-binding material and lectin-binding glycoconjugates were each collected as single fractions (data not shown). About of $55 \%$ of the carbohydrate applied to the column remained in the non-binding fraction, which contained elicitor-active components (figure 5). The purification of the elicitor throughout the whole fractionation procedures led to an increase of specific activity from 14.4 to 88.0 and a yield of $0.05 \%$ of the initial carbohydrate content (table 2).

Uronic acids and mannose, glucose, galactose, and traces of arabinose were found in the elicitor-active Con-A non-binding fraction (table 2), whereas the bound, inactive fraction was composed mostly of mannose (data not shown).

Preliminary glycosyl linkage analysis of the active fraction indicated the absence of 3- and 3-6 linked glucose. According to Ruiz-Herrera (1992), glucans are not found in mycelial cell walls of Zygomycetes, although they can be present in spores of some species, including 


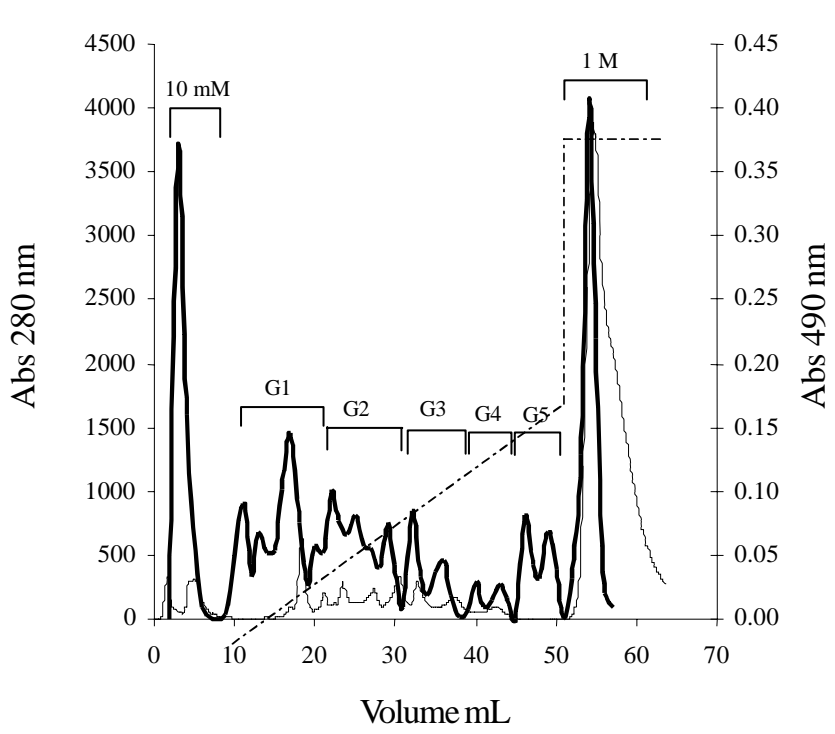

B

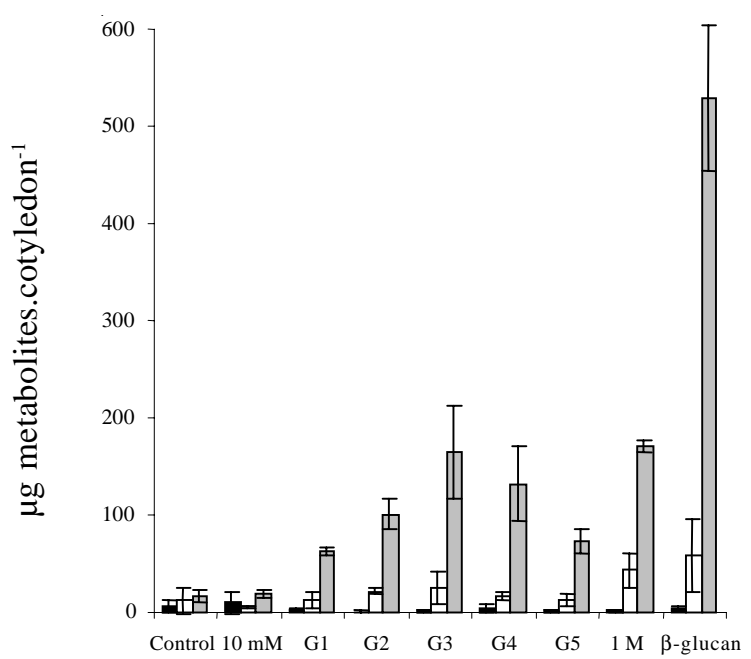

Figure 4. FPLC profile of the precipitated spore extract of M. ramosissimus applied to a Hi Trap Q Sepharose column. (A) Elution profile of (-) carbohydrate content measured by phenol-sulfuric method and expressed by absorbance at $490 \mathrm{~nm}$ and (-) proteins (absorbance at $280 \mathrm{~nm}$ ). (----) Ammonium bicarbonate buffer gradient. Fractions $10 \mathrm{mM}$ (not bound), G1 to G5 (eluted with linear gradient of bicarbonate buffer) and $1 \mathrm{M}$ (eluted with $1 \mathrm{M}$ of bicarbonate buffer) were pooled according to their carbohydrate contents. (B) Eliciting activity of pooled fractions, control (distilled water) and $P$. sojae $\beta$-glucan in soybean cotyledons measured by HPLC of $(\square)$ genistein, $(\square)$ daidzein and $(\square)$ glyceollins in the diffusates. $2.5 \mu \mathrm{g}$ of glucose equivalents of the Mucor elicitor and $0.1 \mu \mathrm{g}$ of the $\beta$-glucan of P. sojae were applied per cotyledon. Data represent the mean \pm standard deviation of triplicates.
A Table 1. Relative proportions of neutral monosaccharides as determined by HPAEC/PAD analysis of the pooled fractions from the Hi Trap Q Sepharose column shown in figure 4.

\begin{tabular}{ccccc}
\hline & \multicolumn{4}{c}{ Monosaccharide (\%) } \\
\cline { 2 - 5 } Fraction & Arabinose & Galactose & Glucose & Mannose \\
\hline 10 mM & 0.5 & 2.0 & 16.5 & 81.0 \\
G1 & 1.0 & 3.0 & 17.0 & 79.0 \\
G2 & 1.0 & 6.0 & 21.0 & 72.0 \\
G3 & 2.0 & 12.0 & 21.0 & 65.0 \\
G4 & 2.0 & 12.0 & 34.0 & 52.0 \\
G5 & 1.5 & 15.5 & 34.0 & 49.0 \\
1 M & 1.5 & 20.0 & 23.5 & 55.0 \\
\hline
\end{tabular}

Mucorales. However, the presence of mannose and uronic acids and the lack of 3- and 3-6 linked glucosyl residues indicate that the eliciting activity from spores of $M$. ramosissimus cannot be attributed to the presence of branched $\beta$-glucans similar to those described for Phytophthora sojae (Ayers et al. 1976a), Saccharomyces cereviseae (Hahn \& Albersheim 1978) or Pyricularia oryzae (Yamaguchi et al. 2000), nor to linear $\beta-1,3$ glucan elicitor from the brown algae Laminaria digitata that is active in tobacco cell suspension cultures (Klarzynski et al. 2000). Furthermore, the Mucor elicitor differs from the mannose-containing elicitors found in autoclaved uridiniospores of the coffee rust (Hemileia vastatrix) since the latter seems to be composed only of neutral sugars (Guzzo \& Moraes 1997). The composition of the Con-A non-binding elicitor fraction determined by silylation (table 2) is consistent with that of a fragment of mucoran, a glucuronic-acid-containing heteropolymer found in Mucor rouxii (Bartinicki-Garcia \& Reyes 1968, Bartinicki-Garcia \& Lindberg 1972). No report of mucoran-like molecules as phytoalexin elicitors has yet been published.

Fractionation of the Con-A non-binding material through a size exclusion column of Bio-gel P2 resulted in two carbohydrate-containing peaks. The activity was detected in a broad peak with apparent molecular mass between 700 and 1,800 Da (data not shown), which would be consistent with a DP of 4-10 for the Mucor elicitor. Low molecular mass elicitors have been isolated from fungal cell walls. Sharp et al. (1984) characterized a branched hepta- $\beta$-glucoside from the phytopathogen Phytophthora sojae capable of eliciting phytoalexin accumulation in soybean cotyledons at concentrations of $10^{-8}$ to $10^{-9} \mathrm{M}$. Yamaguchi et al. (2000) purified a glucopentaose from the rice blast disease fungus that is 


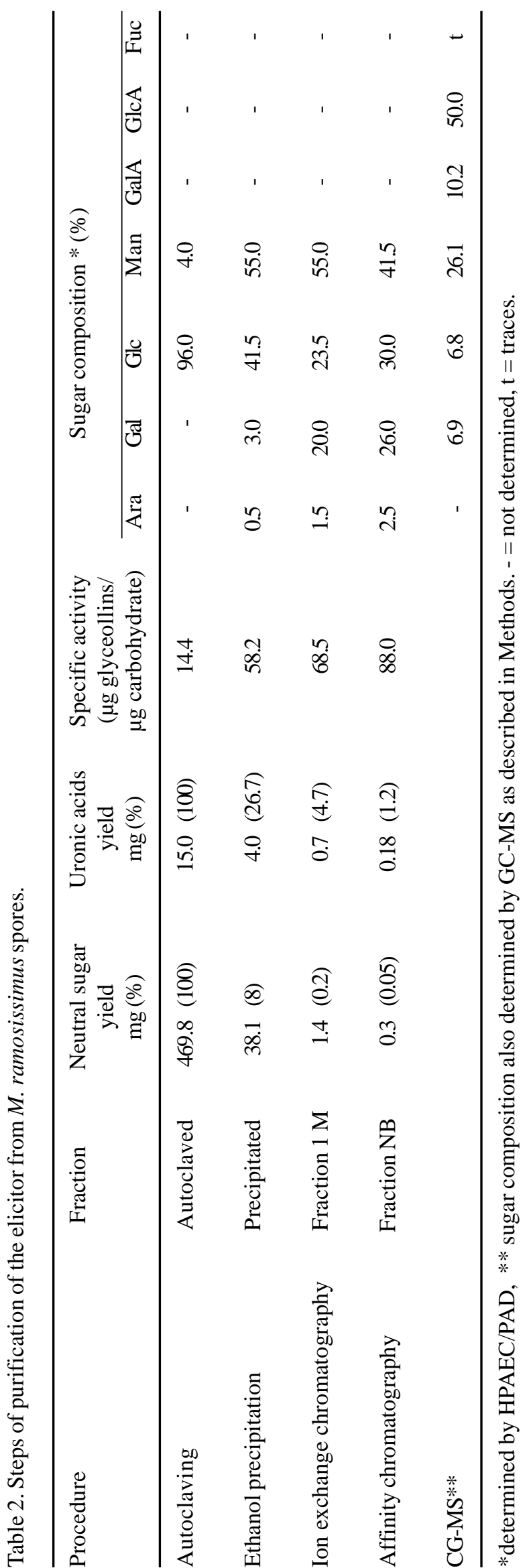

a highly active elicitor of phytoalexin biosynthesis in cell suspension cultures of rice. A $\beta-1,3$-pentaglucan obtained from the algae Laminaria digitata was reported as an active elicitor of defense responses in suspensioncultured tobacco cells (Klarzynski et al. 2000). Chitin and chitosan oligomers with DP from 4-6 have also been described as potent inducers of the phenylpropanoid biosynthetic pathway in soybean leaves (Khan et al. 2003).

Plants have the capacity to recognize and respond to a variety of carbohydrate structures present in microbes to activate plant defense responses regardless of whether they come from a pathogen or a nonpathogen (Hahn \& Albersheim, 1978, Asiegbu et al. 1994, Costa \& Dietrich 1996, Hahn 1996). They are also able to perceive neutral molecules from marine algae (Klarzynski et al. 2000) and acidic oligomers obtained from plant cell walls (Hahn et al. 1981, Nothnagel et al. 1983). In tobacco, neutral glucans derived from brown algae and oligogalacturonides obtained from apple pectin were perceived by suspension-cultured cells as distinct chemical stimuli but had similar elicitor effects (Klarzynski et al. 2000). Soybean tissues can also recognize microbial glucans and uronic acid-containing elicitors derived from plants (Hahn \& Albersheim 1978, Nothnagel et al. 1983) to activate the same defensive responses. Therefore, the Mucor elicitor, which contains uronic acids and seems to be structurally unrelated to

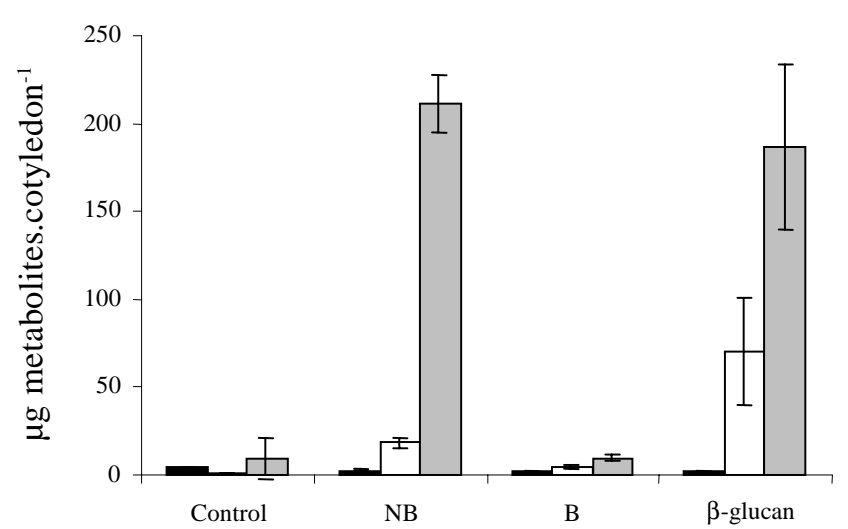

Figure 5. Eliciting activity of non-bound (NB) and bound (B) fractions from the FPLC profile in Con A Sepharose column of the $1 \mathrm{M}$ fraction from the Hi Trap Q Sepharose

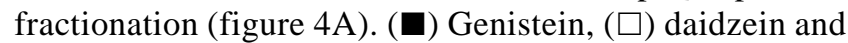
( $\square$ ) glyceollins contents were measured in soybean diffusates by HPLC. Control (distilled water). $\beta$-glucan (elicitor from $P$. sojae). $2.5 \mu \mathrm{g}$ of glucose equivalents of the Mucor elicitor and $0.1 \mu \mathrm{g}$ of the $\beta$-glucan of $P$. sojae were applied per cotyledon. Data represent the mean \pm standard deviation of triplicates. 
any of the previously described fungal or plant elicitors, represents a new and distinct class of carbohydrate signal molecules.

How plants recognize different elicitors to activate the same defense responses remains to be elucidated. Evidence of synergism between different elicitors in several systems suggest that different but interacting signaling pathways exist in plant cells for several of the carbohydrate elicitors identified to date (e.g. Davis \& Hahlbrock 1987, Klarzynski et al. 2000, Yamaguchi et al. 2000, 2002). Further research will be required to determine what receptor(s) in soybean bind the mucoran elicitor fragments, and how the mucoran-induced signaling pathway interacts with the glucan and oligogalacturonide signaling pathways to activate phytoalexin synthesis.

Acknowledgments - Thanks are due to Fapesp (Brazil) for the MSc. fellowship to K. Simões and for the grant to the project (Fapesp 98/05124-8, BIOTASP, Brazil). We also thank CNPq for the research fellow grant to M.R. Braga and S.M.C. Dietrich. This work was also supported by the U.S. Department of Energy (DOE)-funded Center for Plant and Microbial Complex Carbohydrates (DE-FG05-93ER20097).

\section{References}

AGRAWAL, G.K., RAKWAL R., TOMOGAMI, S., YONEKURA, M., KUBO, A. \& SAJI, H. 2002. Chitosan activates defense/stress response(s) in the leaves of Oryza sativa seedlings. Plant Physiology and Biochemistry 40:1061-1069.

ASIEGBU, F.O., DANIEL, G. \& JOHANSSON, M. 1994. Defense related reactions of seedling roots of Norway spruce to infection by Heterobasidion annosum. European Journal of Forest Pathology 25:169-178.

AYERS, A.R., EBEL, J., VALENT, B. \& ALBERSHEIM, P. 1976a. Host-pathogen interactions X. Fractionation and biological activity of elicitor isolated from the mycelial walls of Phytophthora megasperma var. sojae. Plant Physiology 57:760-765.

AYERS, A.R., EBEL, J., FINELLI, F., BERGER, N. \& ALBERSHEIM, P. 1976b. Host-pathogen interactions IX. Quantitative assays of elicitor activity and characterization of the elicitor present in the extracellular medium of cultures of Phytophthora megasperma var. sojae. Plant Physiology 57:751-759.

BARTINICKI-GARCIA, S. \& LINDBERG, B. 1972. Partial characterization of mucoran: the glucuronomannan component. Carbohydrate Research 23:75-85.
BARTINICKI-GARCIA, S. \& REYES, E. 1968. Chemical composition of sporangiophore walls of Mucor rouxii. Biochimica et Biophysica Acta 65:32-42.

BRADFORD, M.M. 1976. A rapid and sensitive method for the quantification of microgram quantities of protein utilizing the principle of protein-dye binding. Analytical Biochemistry 72:248-254.

BRAGA, M.R. \& DIETRICH, S.M.C. 1991. Atividade eliciadora de fitoalexinas em esporos de Trichoderma pseudokoningii Rifai. Hoehnea 18:179-187.

BRAGA, M.R., YOUNG, M.C.M., PONTE, J.V.A., DIETRICH, S.M.C., EMERENCIANO, V.P. \& GOTTLIEB, O.R. 1986. Phytoalexin induction in plants of tropical environment. Biochemical Systematics and Ecology 14:507-514.

CHEONG, J.J., BIRBERG W., FUGEDI, P., COTTI, P., GAREGG, P.J., OGAWA, T. \& HAHN, M.G. 1991. Structure-activity relationships of oligo- $\beta$-glucoside elicitors of phytoalexin accumulation in soybean. The Plant Cell 3:127-136.

CORDEIRO NETO, F. 1992. Fungos indutores de fitoalexinas em rubiáceas nativas e caracterização parcial do agente indutor obtido de Mucor ramosissimus. Tese de doutorado. Escola Paulista de Medicina, São Paulo.

CORDEIRO NETO, F. \& DIETRICH, S.M.C. 1992. Phytoalexin induction by leaf-surface fungi of tropical Rubiaceae. Ciência e Cultura 44:342-344.

COSTA, A.P.P. \& DIETRICH , S.M.C. 1996. Extração de eliciadores de fitoalexinas de fungos do filoplano de rubiáceas nativas. Ciência e Cultura 48:275-277.

CÔTÉ, F., CHEONG, J., ALBA, R. \& HAHN, M.G. 1995. Characterization of binding proteins that recognize oligoglucoside elicitors of phytoalexin synthesis in soybean. Physiologia Plantarum 93:401-410.

DAVIS, K.R. \& HALBROCK, K. 1987. Induction of defense responses in cultured parsley cell by cell wall fragments. Plant Physiology 85:1286-1290.

DE WIT, P.J.G.M. \& ROSEBOOM, P.H.M. 1980. Isolation, partial characterization, and specificity of glycoprotein elicitors from culture filtrates, mycelium and cell walls of Cladosporium fulvum. Physiological Plant Pathology 16:391-408.

DIXON, R.A. \& LAMB, C.J. 1990. Molecular communication in interaction between plants and microbial pathogens. Annual Review of Plant Physiology and Plant Molecular Biology 41:339-367.

DUBOIS, M., GILLES, A., HAMILTON, J.K., REBERS, P.A. \& SMITH, F. 1956. Colorimetric method for determination of sugars and related substances. Analytical Chemistry 28:350-355.

ELLIS, D.H. 1997. Zygomycetes. In Topley and Wilson's Microbiology and Microbial Infections (T. Topley \& W. Wilson, eds.). Edward Arnold, London, p.247-277.

FILISETTI-COZZI, T.M.C.C. \& CARPITA, N.C. 1991. Measurement of uronic acids without interference from neutral sugars. Analytical Biochemistry 197:157-162. 
GARCÉZ, W.S., MARTINS, D., GARCEZ, F.R., MARQUES, M.R., PEREIRA, A.A.P., OLIVEIRA, L.A., RONDON, J.N. \& PERUCA, A.D. 2000. Effect of spores of saprophytic fungi on phytoalexin accumulation in seeds of frog-eye spot and canker-resistant and susceptible soybean (Glycine max L.) cultivars. Journal of Agricultural and Food Chemistry 48:3662-3665.

GOMÉZ, L.D., BRAGA, M.R. \& DIETRICH, S.M.C. 1994. Involvement of active oxygen species and peroxidases in phytoalexin production induced in soybean hypocotyls by an elicitor from a saprophytic fungus. Ciência e Cultura 46:153-156.

GRAHAM, T.L. 1995. Cellular biochemistry of phenylpropanoid responses of soybean to infection by Phytophthora sojae. In Handbook of Phytoalexin Metabolism and Action. (M. Daniel \& R.P. Purkayastha, eds.). Marcel Dekker, New York, p.85-116.

GRAHAM, T.L. \& GRAHAM, M.Y. 2000. Defense potentiation and competency: redox conditioning effects of salisylic acid and genistein. Plant Microbe Interactions 5:181-220.

GRAHAM, T.L., KIM, J.E. \& GRAHAM, M.Y. 1990. Role of constitutive isoflavone conjugates in the accumulation of glyceollin in soybean infected with Phytophthora megasperma. Molecular Plant-Microbe Interactions 3:591-601.

GUZZO, S.D. \& MORAES, W.B. 1997. Purificação e caracterização parcial de um eliciador de fitoalexina em soja, a partir de urediniosporos de Hemileia vastratrix. Fitopatologia Brasileira 22:396-402.

HAHN, M.G. 1996. Microbial elicitors and their receptors in plants. Annual Review of Phytopathology 34:387-412.

HAHN, M.G. \& ALBERSHEIM, P. 1978. Host-pathogen interactions. XIV. Isolation and partial characterization of an elicitor from yeast extract. Plant Physiology 62:107-111.

HAHN, M.G., DARVILL, A. \& ALBERSHEIM, P. 1981. Hostpathogen Interactions. XIX. The endogenous elicitor, a fragment of a plant cell wall polysaccharide that elicits phytoalexin accumulation in soybeans. Plant Physiology 68:1061-1169.

HAHN, M.G., DARVILL, A., ALBERSHEIM, P., BERGMANN, C., CHEONG, J.J., KOLLER, A. \& LÓ, V.M. 1992. Preparation and characterization of oligosaccharide elicitors of phytoalexin accumulation. In Molecular Plant Pathology, v.2: A practical approach. Oxford University Press, Oxford, p.103-147.

KEEN, N.T. 1978. Phytoalexins - efficient extraction from leaves by a facilitated diffusion technique. Phytopathology 68:1237-1239.

KHAN, W., PRITHIVIRAJ, B. \& SMITH, D. 2003. Chitosan and chitin oligomers increase phenylalanine ammonialyase and tyrosine ammonia-lyase activities in soybean leaves. Journal of Plant Physiology 160:859-863.
KLARZYNSKI, O., PLESSE, B., JOUBERT, J-M., YVIN, J-C., KOPP, M., KLOAREG, B. \& FRITIG, B. 2000. Linear $\beta-1,3$ glucans are elicitors of defense responses in tobacco. Plant Physiology 124:1027-1037.

NOTHNAGEL, E.A., MCNEIL, M. \& DELL, A. 1983. Hostpathogen interactions. XXII. A galacturonic acid oligosaccharide from plant cell wall elicits phytoalexins. Plant Physiology 71:916-926.

NÜRNBERGER, T. 1999. Signal perception in plant pathogen defense. Cellular and Molecular Life Science 55:167-182.

PAXTON, J.D. 1995. Soybean phytoalexin: elicitation, nature, mode of action and role. In Handbook of Phytoalexin Metabolism and Action. (M. Daniel \& R.P. Purkayastha, eds.). Marcel Dekker, New York, p.69-83.

PELICICE, F.M., DIETRICH, S.M.C. \& BRAGA, M.R. 2000. Phytoalexin response of fifteen Brazilian soybean cultivars. Revista Brasileira de Fisiologia Vegetal 12:45-53.

RIVERA-VARGAS, L.I., SCHMITTHENNER, A.F. \& GRAHAM, T.L. 1993. Soybean flavonoid effects and metabolism by Phytophthora sojae. Phytochemistry 32:851-857.

RUIZ-HERRERA, J. 1992. Fungal glucans. In Fungal cell wall. (J. Ruiz-Herrera, ed.). CRC Press, Boca Raton, p.59-67.

SCHIPPER, M.A.A. 1973. A study on variability in Mucor hiemalis and related species. Studies in Mycology 4:1-40.

SHARP, J.K., VALENT, B. \& ALBERSHEIM, P. 1984. Purification and partial characterization of a $\beta$-glucan fragment that elicits phytoalexin accumulation in soybean. Journal of Biological Chemistry 259:11312-11320.

SHIBUYA, N. \& MINAMI, E. 2001. Oligosaccharide signaling for defence responses in plant. Physiological and Molecular Plant Pathology 59:223-233.

YAMAGUCHI, T., YAMADA, A., HONG, N., OGAWA, T. \& ISHII, T. 2000. Differences in the recognition of glucan elicitor signals between rice and soybean: $\beta$-glucan fragments from the rice blast disease fungus Pyricularia oryzae that elicit phytoalexin biosynthesis in suspension-cultured rice cells. The Plant Cell 12:817-826.

YAMAGUCHI, T., MAEHARA, Y., KODAMA, O., OKADA, M., MATSUMURA, M. \& SHIBUYA, N. 2002. Two purified oligosaccharide elicitors, $\mathrm{N}$-acetychitoheptaose and tetraglucosyl glucitol, derived from Magnaporthe grisea cell walls, synersgistically activate biosynthesis of phytoalexin in suspension-cultured rice cells. Journal of Plant Physiology 159:1147-1149. 
YOSHIKAWA, M., YAMAGUSHI, K. \& MASAGO, H. 1981. Release of soluble phytoalexin elicitor from mycelial walls of Phytophthora megasperma var. sojae by soybean tissues. Plant Physiology 67:1032-1035.
YORK, W.S., DARVILL, A.G, MCNEIL, M., STEVENSON, T.T. \& ALBERSHEIM, P. 1985. Isolation and characterization of plant walls and cell wall components. Methods in Enzymology 118:3-40. 